\title{
Indigenous Knowledge and Conflict Management in Africa : A Study of Proverb Use in Conflict Management among Hausas of Northern Nigeria
}

\author{
Adeyemi J. Ademowo', Ahmad Ahmad Nuhu \\ ${ }^{1}$ Department of Sociology, Afe Babalola University, Ado-Ekiti \\ ${ }^{2}$ Conflict, Peace and Strategic Studies Unit, Afe Babalola University, Ado-Ekiti

\begin{abstract}
This paper examines the place of indigenous knowledge in conflict management and peace building, using the Hausa speaking people of Northern Nigeria as a case study. The paper argues that traditional knowledge are intrinsically valuable as they are veritable tools in maintaining peace and peaceful coexistence among the people. In this context, the use of and the place of proverbs in conflict management is underscored. We subjected twenty (20) randomly selected Hausa proverbs to discourse analysis in order to examine their implications for conflict management and peace building. Results show that the analysed proverbs, beyond their ordinary or literal meanings, have implications for conflict management. The paper therefore avers that anybody with a good understanding of proverbs would appreciate conflicts as intricate part of existence and harmonious living hence would avoid actions and inactions that would promote violence. Furthermore, the work suggests that efforts to promote the use of indigenous methods of conflicts management should be encouraged.
\end{abstract}

Keywords: Indigenous knowledge, Conflict Management, Proverbs, Hausas, Africa

\section{INTRODUCTION}

The African setting is truly a remarkable one. Africa is home to over a thousand ethnic groups, speaking over 1,000 languages. Yet, Africa seems to always be depicted as a single culture; meaning there is this common misconception about Africans sharing the same culture. Looking at this from a realist's viewpoint, over 1,000 different ethnic groups cannot possible be united under a single culture. However, the beauty of Africa is such that, there is a kind of common frame of culture which most groups share. This commonality can be found in our concepts of kingship (where kings oversee societies/towns); our mode of farming; our family structure; our use of rhythm in music; functions of dancing and mask wearing; our adherence to values (social, moral, religious, etc.) and norms, etc are the some of the common grounds most African cultures share.

Again, in a typical Traditional African society norms and values are embedded mostly in oral form, in our proverbs, folktales, wise sayings, idioms, and spiritual beliefs, etc. The foregoing are part of what we referred to as the harbingers of African Indigenous Knowledge, which are complex mental processes that interpret and sustain the interactive practices that constitute the accumulated stock of successful cultural adaptations to environmental circumstances-both natural and social-that communities have made over their long histories of ecological interface (Doughty, 2005: p.5). These indigenous knowledge system is the frame through which the society views the world. It touches all facets of life of the people - ecology, soil, agriculture, technology, architecture, governance, social welfare, conflict resolution, music, arts, etc.

Irrespective of the culture, ideology, genes, clan or respect you share with one another, disputes will always come up, as they are a reality of life. Each of us has our own perspectives, our own interests, our own resources, our own aspirations, beliefs and values. It is no wonder, then, that as we interact with one another, we sometimes disagree about what has happened or about what ought to happen. We hurt us one another; have to forgive and find means of staying together for diverse reasons. Furthermore, Africans seem to have their our unique ways of handling disputes in different cultures. These are sometimes more esoteric than law and the tenets of human rights - they are customs, traditions (that includes proverbs, folktales, wise sayings, etc.). 
Conflict resolution in traditional Africa is geared towards reconciliation, maintenance and improvement of social relationships. The significance and efficacy of the processes lie in the fact that they strive to restore a balance, to settle conflict and eliminate disputes. Trivial issues are handled at the family level; other major issues could end up being settled at the spiritual level, at the behest of ancestors and/or the gods. That was (is) how Africans are, and also how the Hausa people go about their lives channeling veritable paths to manage their unending conflicts.

\section{INDigenOUS KNOWLEDGE AND CONFLICT MANAGEMENT}

Indigenous, traditional or local knowledge refers to the knowledge and proficiency unique to a given society or culture, which encompasses 'the cultural traditions, values, beliefs, and worldviews of local people' (Magni, 2016:5), including specific beliefs, rules and taboos that are part of the customary law of a specific group (Mu Xiuping and Kissya, 2010 cited in Magni, 2016). To Hoppers (2005; cited in Osman, 2009:2), indigenous knowledge refers to knowledge and practices - explicit or implicit, used in the management of socioeconomic, ecological and spiritual facets of life. These are stored in the collective memory of members of the community and transferred onto future generations via storytelling, folktale, wise sayings, music, art, proverbs etc.

\section{INDigENOUS CONCEPT OF CONFLICT MANAGEMENT/RESOLUTION}

Traditional conflict resolution processes are part of a well-structured, time-proven social system geared towards reconciliation, maintenance and improvement of social relationships (Osei-Hwedie and Rankopo, 2012). The methods, processes and regulations are deeply rooted in the customs and traditions of Africans. The importance and efficacy of the processes lie in the fact that they strive to restore a balance, to settle conflict and eliminate disputes (Ademowo 2015; Osei-Hwedie and Ronkopo, 2012:1). The traditional processes are relatively informal and thus, less standardized - those who use them are more comfortable in familiar territory/environment. Peacebuilding is the main concern of traditional African societies. Atogo (in Asilia, 2013), writes that peacebuilding is an organic process, which is initiated from the grassroots level. He posited that only when members of community take ownership of peace processes that peace can be sustainable. Hence, the indigenous African way of conflict management/resolution, is in fact aiming at peacebuilding. Loveness and Mathew (2017), asserted that African indigenous systems 'foster constructive change from the personal, rational, structural and cultural dimensions in order to construct good relations among societies'. Huyse and Salter (2008:10; in Loveness and Mathew, 2017:3), states that most African indigenous knowledge system approaches strongly support the notion of restorative justice, where the community, victim and the offender are involved in the healing, restoring and compensating sessions in the entire community.

Traditional conflict resolution mechanism is therefore described as a social capital, with "capability of social norms and customs to hold members of a group together by effectively setting and facilitating the terms of their relationship... sustainability facilitates collective action for achieving mutually beneficial ends" (Fred-Mensah, 2005:1; in Osei-Hwedie and Ronkopo 2012:3). Conflict resolution involves a complex system of forces surrounding the parties in the conflict. It is a healing process in which all stakeholders contribute positive energy. The task is to re-establish the energy flow within individuals, families and communities so as to re-build social harmony. In this context, the role of chiefs, elders, family heads, and others is not only to resolve conflicts but also to anticipate and stop/or intercept conflicts (Ademowo and Adekunle, 2011). They do this using language - proverbs, wise sayings, and even songs - to warn, encourage and discourage certain practices. For instance, in a Yoruba society, individuals are advised and encouraged using proverbs as ogbon j'agbara; meaning "wisdom is powerful than might" (Ademowo and Balogun, 2014: 6); among the Igbos, for instance, they can encourage one another with proverbs like Ónyé ndidi n"eri ázu ukpo; literally meaning "one patient eats the dry fish". This can be further explained as "determination and patience is the key to success - a patient dog eats the fattest bone" (Onyinye, 2015:5). Among the Bantu family, a popular Nguni proverb reads: "umuntu ngu-muntu ngabantu" which literally translates into "I am because we are" (Akinyoade, 2016). This particular proverb promotes collectivism, cooperation, selflessness, solidarity - aimed at maintaining communities with justice and mutual caring, which is central to indigenous African culture. This Nguni proverb can be further supported by the common Hausa 
proverb hannu daya baya daukan jinka; which literally means "one hand cannot lift a hut". This can as well be explained with the English proverb "one tree cannot make a forest".

Basically, proverbs are used resourcefully in a typical traditional African society. To Mbiti (1995), proverbs have rich vocabulary of words, phrases, combination of words, symbols, pictures, allusions and comparisons hence if culture were an important tool of cohesion and development; if language were a carrier of culture and if the relationship between language and culture were like the two-edged sword, then the role of proverbs as a metaphorical coding of language could not be glossed over (Adeshina 2015). So, as far as groups of people are endowed with definite ways of expressing culture, proverbs is bound to form an integral part of this conveyance. This might explains why Ademowo and Balogun (2014:1) opine that no human society can exist to experience development without effective use of proverbs through language use. Their submission seems to support the earlier assertion of Ajayi and Raji (1995:636) who hold that proverbs essentially across languages and cultures form part of the codes of behaviour and exemplify their use for the transmission of tribal wisdom and rules of conduct. Proverbs are essential in daily living; they are used in daily interpersonal/group interactions among and between peers, in families, by elders, by leaders and so on. In conflict management or conflict resolution, proverbs are used to a high degree. Proverbs are used during settlement of disputes, before a dispute sets in, and even after dispute has been settled. Indeed, dexterity in the use of proverbs is an essential condition for dispute settlers.

\section{ReVisiting CONFlict ANd CONFlict Management}

Conflicts, coined from the Latin verb Confligere which means to clash or engage in a fight is commonly misunderstood as the direct opposite of peace. In simple terms, conflict refers to a relationship between two parties who have, or think they have incompatible goals. Without a preceding relationship there cannot be conflict. In a conflict, a prior relationship is needed, and then the parties perceive or imagine that the realization of their goals is mutually exclusive. Peace scholars however, look beyond the traditional perception of conflict, as it lends itself to negativism hence, conflict can also be viewed as not necessarily destructive, rather as something productive depending on how we perceive and handle it. Viewed as such, conflict could be an opportunity for change pointing to problems, increasing self-awareness, improving solutions, fostering change (Ademowo, 2016).

Conflict Management is used both in specific term to resolve, prevent or limit conflict, especially violent ones, while building up the capacities of all parties involved to embark on peace building. To Bercovitch (2005), the "purpose of conflict management, whether undertaken by the parties in conflict or whether involving the intervention of an outside party, is to affect the entire structure of a conflict situation so as to contain the destructive components in the conflict process (e.g. hostility, use of violence) and help the parties possessing incompatible goals to find some solution to their conflict." Since conflict cannot be totally eradicated, it becomes imperative to find ways of managing conflict, and also, the way we handle conflict determines its outcome - positive or negative.

Thomas-Kilmann Conflict Model, developed by Kenneth Thomas and Ralph Kilmann in the 1970s, identified five conflict handling styles, with varying levels of assertiveness or cooperativeness (Akinyoade, 2016: p.35). They argued that individuals have preferred conflict handling styles and it is influenced by their personality types and life experiences. These are:

1. Avoiding - when a person deliberately evade, ignore, withdraw or delay response to conflict; which doesn't allow for addressing the conflict.

2. Accommodating - when an individual gives in to other's demands.

3. Compromising - willingness to sacrifice part of your goals and persuade the other party to do same, in order to find common ground.

4. Competing or forcing - an attempt to achieve one's goal at the expense of the other party.

5. Collaborative or cooperating - team effort geared towards reaching a mutually beneficial outcome; win-win (Akinyoade, 2016). 
Indigenous Africans handled conflict in a rather fascinating manner. They applied negotiation, bargaining, dialogue, mediation, conciliation, collective personhood, adjudication, etc (Ademowo 2016). Modern day US-championed Alternative Dispute Resolution (ADR) is regarded by many scholars as "African Dispute Resolution", as they are initiatives gotten from Africa. A very good example is the Ubuntu conflict handling style of the Bantu family among South Africans. It is philosophy based on collective responsibility among human beings to live for common benefit. Others are Adzo, Cofono, House of Palaver, among others (Ademowo, 2015)

\section{The Hausas, Proverbs Use And Conflict Management}

The first Hausa states began to develop in the Sahel around 500-700 AD (The Saylor Foundation). Saleh Yusuf S. (2014) writes "an increase in traffic along the trans-Sahara trade routes to the Hausa town expanded the commerce in slaves, gold and kola from the savannah and forest regions to the South. The thriving trade generated wealth that enabled the rulers of these towns to establish states. The seven true ${ }^{e e}$ Hausa States- Biram, Kano, Rano, Katsina, Daura, Zazzau, and Gobir which the Hausa considered the core of Hausa land, emerged during this period."

Hausa language is the most spoken language in West Africa. "It has more than fifty million (50 million) native speakers and about fifteen million non-native speakers."- (NALRC, 2000). In Nigeria, Hausa is mainly spoken in the Northern part of the country. "Hausa identity is particularly remarkable for its multiethnic and intercultural composition in Hausaland, as well as in its Diaspora. People from various ethnic origins have become Hausa over the years through cultural and linguistic assimilation. Hausa language and culture have been very receptive to influences from other cultures and civilizations." - (NALRC)

The study of Proverbs is prevalent among the Hausas as it offers a useful means of transmitting culture, social morality, manners and ideas of a people from one generation to another. Proverbs expresses the folk ideas, which inspire the thought and action of a given group of people. A Proverb is a saying which expresses the simple and physical truth based on common sense and social experience of people. "It is this interactive effort involving sharp-witted analysis and judgment, which can make a proverb in the mouth of a skilled proverbist a verbal act of great fitness." (Ibekwe, 1998:p.2; cited in Usman A, 2014:1). Proverbs are capable of having more than one meaning, thus a proverb is not limited to just a single circumstance. Proverbs also demand consideration on the part of those who use and hear them, and then adjudge whether it has been used correctly and effectively.

Aside the aesthetic and metaphorical value in proverbs, it presents a striking statement that expresses a truth of experience. Its beauty and some delight is that what it says is readily perceived and accepted as an incontrovertible truth (Ademowo and Balogun, 2014:3). In principle, their values do not lie only in what they reveal of the thoughts of the people; proverbs are models of compressed or forceful language that make people behave according to norms and mores of the land (Ademowo and Balogun, 2014: p.4).

The Hausa term for proverb is "Karin Magana" and it is one of the oldest and most important genres of tradition, which form part and parcel of the Hausa culture. They are wise sayings, which form an essential part of the experience and way of life of the people who produce them.

There is a common Hausa saying "Kunne ya girme kaka" - which means "the ear is older than grannies." This is simply acknowledging that no one can categorically attribute a particular proverb to any single person.

Among the Hausas, proverbs are aimed to check their cultural excesses - they aim to advise, rebuke and/or suggest. Usman A (2014:2) posits that "proverbs relate to the day-day lives of the people who produce them; and their aspiration, morality, religion, history, thinking, expectation - in short, everything about their world views." The use of proverb among the Hausas is therefore seen from their total life pattern - ranging from entertainment, games and other serious issues. The effect of proverbs on the people depends on the aptness with which they are employed in a given situation and on the subject matter, style, and forms of words with which they are dressed. People tend to be smitten by proverbs due to its sheer elegance - we are almost compelled to agree and accept them. 
In a typical Hausa society, people relate with each other a lot, to an extent that most people have what is called "majalisa" which means a place of hanging out. Cliques form their majalisa and hangout there virtually every day. At such gatherings, a wide range of topics are discussed, ranging from politics, state of the community, the future, marriage life, religious discourses, sports, etc. The gentlemen communicate in mesmerizing manner most times, as some can use proverbs in buttressing virtually every point they make. In places like markets, motor parks, 'indomie/suya' joints, viewing centers, individuals use proverbs in outstanding manners. In most places, once you cannot use powerful proverbs in discourses, one automatically becomes an outcast in further discussions. Also, parents, elders, neighbors, all use proverbs in advising, encouraging, cautioning, appreciating and emphasizing on things and people.

Let us examine twenty (20) randomly selected proverbs and how they are linked to conflict management. The proverbs are gotten anonymously extracted through conversations.

It is also important to note that the images presented or represented in proverbs are culturally defined and may differ from one culture to another, society to society and even from generation to generation. A single proverb could be employed in several situations as well.

\section{Proverb: Zama lafiya yafi zama dan sarki}

Translation: It is better to live in peace than to be a prince

\section{Proverb: Hakuri maganin zaman duniya}

Translation: Patience is a universal remedy

Implication: these two proverbs are very similar both in meaning and in application. Both underscored the place of peace in human existence and that peace is priceless - one must be patient and not be in desperate. The relationship of the above mentioned proverbs to Conflict Management is to stop dispute and eradicate hostilities between the conflicting parties - and what better way than to opt for a peaceful settlement!

\section{Proverb: Hali da nagarta kesa a kulla alaka}

Translation: Ties are built on the basis of one's personality and integrity

Implication: for other individuals/groups to form an alliance with you, trust is prerequisite. There cannot be trusted if the individual/group questions your character and integrity.

In Conflict Management, trust is a resource that is highly scarce - most conflicts started due to mistrust in the first place. Thus, building trust between two conflicting parties is crucial in achieving success.

\section{Proverb: Shinfidar fuska tafi ta taburma}

Translation: A smiling face is better than the offer of a mat

Implication: this proverb implies that a smiling face is better than the entire offer that will be given (to a guest). A friendly face tends to make people you relate with feel secured and welcomed. Thus, to the Hausas, a smiling face to a guest is better than all that will be offered to the guest throughout his/her visit/stay. When a conflict is to be resolved, normally there is dialogue then negotiation and so on. If one of the conflicting parties come to the negotiating table with an honest smile, positive outcome is likely to be reached in the end.

\section{Proverb: Abinda mutum ya shuka shi zai girba}

Translation: You reap what you sow

Implication: this proverb is used to counsel those with bad behaviours. A person must accept the consequences of his/her actions, somehow; now or later. Relating this to Conflict Management, this proverb could be used to remind a person/group against making a decision he/they will regret later.

6. Proverb: Komai yayi farko zaiyi karshe

Translation: Everything that has a beginning has an end 
Implication: this proverb implies that whatever situation one is in, it will not last forever. The proverb is usually employed to encourage patience, which is an invaluable value. This could prove useful in Conflict Management in the sense that the main aim of Conflict Management is to find common ground and do away with hostilities.

\section{Proverb: A bar kaza cikin gashinta}

Translation: Do not pluck the chicken

Implication: this proverb is similar to the English saying "let sleeping dogs lie"; meaning letting things the way they are. One should not attempt to investigate things that are better left hidden - just as the chicken is better with its feathers and hair as against when it is plucked and its ugly sight revealed.

Relationship of this proverb to Conflict Management can be viewed thus; one shouldn't go to the extent of digging too deep into a matter that had been closed long ago; doing so could trigger negative consequences which might affect relationships.

\section{Proverb: Ga fili ga mai doki}

Translation: Here is the field; and here is the horse rider

Implication: this proverb suggests that both the atmosphere and situation are conducive for an act proposed, unless one has suddenly developed cold feet. A rider on horse-back is offered sufficient field to play, run and gallop will definitely take the opportunity unless the person is unserious.

The relationship this proverb has with Conflict Management can be viewed from the 'confrontation' stage of conflict. The proverb is mostly deployed when a person wants to dare another into doing something challenging. It could also be used to call off a person's bluff.

\section{Proverb: Kwai a baka yafi kaza a akulki}

Translation: an egg in the mouth is worth more than a chicken in the cage

\section{Proverb: Abu ga hannu shine mutum}

Translation: An item in the hand is what makes one a person

Implication: both proverbs are similar to the English saying "A bird in hand is worth two in the bush." This means having the personal ownership of something, no matter how little, is better than an imagined or expectation of something big which is out of reach.

These proverbs' relationship to Conflict Management can be viewed from the 'negotiation' angle in a conflict situation. The proverbs encourages people to be pragmatic and not to be over ambitious.

\section{Proverb: Ana kukan targade sai ga karaya ta samu}

Translation: Just when we were complaining of a dislocation then suddenly a fracture was detected

\section{Proverb: Ana kukan ba'a koshi ba, sai ga baqi sun zo}

Translation: As we were complaining we were still hungry, guests showed up

Implication: just as one is complaining over trivial issues, he suddenly detects more serious ones. Looking at the first proverb, one can agree that a dislocation far better than a fracture, but before the dislocation was treated, a fracture is discovered. What else is expected of a hungry person who receives important guests who need to be fed? Definitely one will be in a dilemma of how to handle the situation. Thus, when one suddenly finds him/herself in a very difficult situation or dilemma one could use this proverb to lament over the predicament.

The connection of these proverbs to Conflict Management could take the view point of when you think the problem you are to solve is not as big a deal, suddenly you uncover bigger ones.

\section{Proverb: komai nisan jifa qasa tayi}

Translation: Whatever that goes up must come down 
14. Proverb: Komai nisan dare, gari zai waye

Translation: No matter the length of the night, dawn will surely break

Implication: Both proverbs mean that no matter how long it takes everything has an end. These proverbs are used to uphold and stress the value of patience. No matter the hardship if one exercise patience it would come to an end. Thus with patience, anything could be achieved just as the stone thrown up would gradually slide down or the night never continues but surely ends in day break/dawn. These proverbs could be used to emphasize or stress the value of patience.

The connection of these proverbs to Conflict Management could be employed by a group/party in a conflict, thus helping in stirring patience.

\section{Proverb: Abokin barawo, barawo ne}

Translation: The friend of a thief, is a thief

16. Proverb: Zama da madaukin kanwa, shi ke sa farin gashi

Translation: Being in the company of the potash carrier makes one have a dusty/grey hair

Implication: These proverbs suggest that the habit of a person can affect those in his company. Adversely the proverbs also suggest that for you to know much about a person, study or look at the characters of the company he keeps because one way or the other he or she would be affected by the people around him/her. These proverbs could be used to caution or warn a person to be careful of the company he keeps especially if they are known to be of negative characters; for he or she could be judged according to their behaviors.

The connection of these proverbs to Conflict Management could be viewed from the aspect of external influence in a conflict situation. They suggest that the kind of companion (advisors) an individual/group has/have a great influence on the attitude and behavior of the individual/group.

17. Proverb: Sabo da kaza baya hana a bita a yanka

Translation: Your bond (familiarity) with your chicken does not stop you from slaughtering it

Implication: normally, we rear chicken in our households. The owner would be so much concerned with the eggs of the chicken up to the moment of hatch. It does not stop there, one could find out the owner recognizes each and every one of them - a sort of attachment is formed. Nonetheless, this does not stop the owner from slaughtering and eating the chicken in the end.

In Conflict Management, justice, equality and equity form the base as well as the super structure. This proverb shows that no matter how influential and close someone is, he/she can be brought to justice should he/she misbehaves.

\section{Proverb: Yaro bai san zafi na wuta ba sai ya taka}

Translation: A child does not know fire hurts until he touches it

Implication: A person will only know the effect of certain things when he/she experiences it firsthand. Just as a child sees fire as a toy before his/her first encounter, so also people tend to take certain things for granted. This proverb could be used to caution someone about to make a bad decision.

\section{Proverb: Ihun neman ceto kayita inda za'a jiyoka}

Translation: Cry out for help where you will be heard

Implication: this is a straight forward proverb. Shouting for help where no one can hears is a waste of time. It also means that when you have a complaint, approach a powerful authority/third party; someone that can influence the matter.

In Conflict Management and Conflict Transformation, there is the presence of "External Actors", who are usually third parties that can intervene in a particular dispute. Should one find himself/herself in a 
dispute with another person/group, reaching out to the right External Actor tends to put one in position to be rescued, for the matter to be resolved.

\section{Proverb: Kaso ma dan uwanka abinda kake so ma kanka}

Translation: Love for your brother (fellow human) what you love for yourself

Implication: this proverb is simply suggesting that one should adopt cooperation and do away with selfishness. In most conflict situations (family, community and even international levels), a "selfcentered" stand taken by the disputants is usually what prolong conflicts. Understanding the plight and circumstance of other people will make one to adopt a win-win solution to their problems.

\section{CONCLusion}

From the above presentation/analysis, one will see that the Hausa people, as typical traditional African people, use their Proverbs (indigenous knowledge) in transmitting knowledge, checking social vices, exhibiting kindness, issuing warnings and cautions; which are often expressed metaphorically. The paper has also tried to establish that the proverbs could be used in numerous circumstances and ways for the sake of conflict management and peace building.

\section{REFERENCES}

[1] Abdulqadir Z (2015). Thematic Analysis of Some Selected Hausa Proverbs. Arts and Design Studies Journal. Retrieved at file:///C:/Users/HP\%20PC/Downloads/19030-21278-1- PB.pdf (19/01/2017)

[2] Ademowo, A.J (2016) Viewpoints in Conflict and Peace Management. Ibadan: TicTacToe Consulting. 96pp

[3] Ademowo, A.J (2015) 'Conflict Management in Traditional African Society' In Ademowo, A.J and Oladipo T.D (Eds.) Engaging the Future in the Present: Issues in Culture and Philosophy. Ibadan: Hope Publications

[4] Ademowo, A.J. and Noah Balogun. (2015) Postproverbial Constructions and Selected Sex-Related Yoruba Proverbs/ Proverbial Expressions. International Journal in Management \& Social Science (IJMSS) Vol. 9, Sept

[5] Ademowo, A.J (2014) 'Of African Development, Culture and the African Intellectuals' in Francis Offor and Ademowo, A.J (Eds.) (2014) Humanism and Existential Predicaments: Essays in honour of Olusegun Oladipo Ibadan: Hope Publications.

[6] Ademowo, A.J. and Noah Balogun. (2014). Proverbs and Conflict Management in Africa: A Study of Selected Yoruba Proverbs and Proverbial Expressions International Journal of Literature, Language and Linguistics, Vol. 1, No. 2, 1(1)

[7] Ademowo, A.J. and Noah Balogun. (2014). 'Izreke, Vrednosti I Pitanje Razvoja U Savremenoj Africi: Slučaj Joruba Poslovica' (Proverbs, Values and the Development Question in Contemporary Africa: A Case Study of Yoruba Proverbs). Antropologija. No. 14 (2),

[8] Ademowo A.J. and Dapo Adekunle (2013) 'Law in Traditional Yoruba Philosophy: A Critical Appraisal' Caribbean Journal of Philosophy, Volume 2, No. 1

[9] Adesina, O.L (2015) "Pragmatic Use Of Some Proverbs On "Egungun" Among Yoruba Speakers" IOSR Journal Of Humanities And Social Science (IOSR-JHSS)Volume 20, Issue 12, Ver. II (Dec. 2015)

[10] Akinyoade, D. (2016). Peace for All - Empowering Nigerians for a Culture of Peace. Lagos: Helmsman Publishers, Helmsman Innovations Global Ltd.

[11] Asilia Elimu (2013). Indigenous Knowledge on Conflict Resolution Mechanisms. A project of the National Museum of Kenya supported by the Goethe-Institut Kenya.Retrieved from http://elimuasilia1.blogspot.com.ng/2013/03/indigenous-knowledge-on-conflict.html (22/11/2017)

[12] Giorgia Magni (2016). Indigenous Knowledge and Implications for the SustainableDevelopment Agenda. "Paper commissioned for the Global Education Monitoring Report 2016, Education for people and planet:Creating sustainable futures for all". Retrieved from http://unesdoc.unesco.org/images/0024/002456 /245623E .pdf (5/11/2017)

[13] Howard A. Doughty (2005). Book Review: Indigenous Knowledge in a Postcolonial Context.The Innovation Journal: The Public Sector Innovation Journal, Vol. 10(3). Retrieved from https://www.inno vation .cc /book-reviews /doughty_hoppers1a_v10i3a15.pdf (5/11/2017)

[14] Jabob Bercovitch's (Political Science lecturer at University of Canterbury) publication on "Conflict and Conflict Management in Organizations: A Framework for Analysis." Retrieved at http://legacy.earlham .edu/ chriss/ConflictRes/pdf\%20files/Conflict.Conflict\%20Management\%20in\%20Organizations.pdf $(30 / 01 / 2017)$ 
Indigenous Knowledge and Conflict Management in Africa : A Study of Proverb Use in Conflict Management among Hausas of Northern Nigeria

[15] Lawal, A., Ajayi, B. \& Raji, W. (1995). A pragmatic study of selected pairs of Yoruba proverbs. Journal of Pragmatics, 635-652

[16] Loveness N. and Mathew S. (2017). The role of Indigenous Knowledge Systems in Peacebuilding: A Case of Umguza District, Zimbabwe. International Journal of Politics and Good Governance, Volume VIII, No. 8.1. Retrieved from www.onlineresearchjournals.com/ijopagg/art/230.pdf (22/11/2017)

[17] Mbiti, J. S. (1995) Children Confer Glory at Home: Introduction to the African Proverb Series. In Mokitimi, Proverbs of the Basotho. Ibadan: Daystar.

[18] National African Language Resource Center publication on "Language and Culture - Studying Hausa in the US. " Retrieved at http://www.nalrc.indiana.edu/brochures/hausa.pdf $\quad(28 / 01 / 2017)$

[19] Onyinye AnneNwankwo (2015). Igbo Proverbs in the Context of Early Communicative Competence and Social Stability. IOSR Journal Of Humanities And Social Science, Vol. 20(9). Retrieved from http://www.iosrjournals.org/iosr-jhss/papers/Vol20- issue9/Version-6/J020965461.pdf (5/11/2017)

[20] Osei-Hwedie K. and Rankopo M. (2012). Indigenous Conflict Resolution in Africa: The Case of Ghana and Botswana. Retrieved from home.hiroshima-u.ac.jp/heiwa/pub/E29/e29-3.pdf (22/11/2017)

[21] Osman Anwar (2009). Indigenous Knowledge in Africa: Challenges and Opportunities. An Inaugural Lecture. Retrieved from https://www.ufs.ac.za/docs/librariesprovider20/centre-for-africa-studiesdocuments/alldocuments/osman-lecture-1788-eng.pdf?sfvrsn=0 (5/11/2017)

[22] Saleh Yusuf S (2014). A contrastive Analysis of English and Hausa Proverbs in Selected Texts. B.Ed Thesis submitted to Department of Arts and Social Science Education, Ahmadu Bello University, Zaria. Retrieved at http://kubanni.abu.edu.ng:8080/jspui/bitstream/123456789/6456/1/A\%20CONTRASTIV E\%20ANALYSIS\%20OF\%20ENGLISH\%20AND\%20HAUSA\%20PROVERBS\%20IN\%20SELECTED \%20TEXTS.pdf (27/01/2017)

[23] The Saylor Foundation, retrieved at https://www.saylor.org/site/wp- content/uploads/2012/10/HIST10110.2.2-HausaKingdom-FINAL1.pdf (27/01/2017)

[24] Usman A.K. (2014). An Annotation of Selected Hausa Proverbs. Journal of Modern Review. Retrieved at http://www.academicstar.us/UploadFile/Picture/2015-1/201512064445119.pdf (19/01/2017)

\section{AUTHOR'S BIOGRAPHY:}

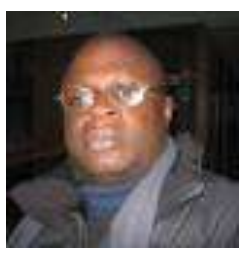

Adeyemi J. Ademowo (PhD) is a product of University of Ibadan, Ibadan; United States Institute of Peace, Washington D.C and; BIARI, Brown University, Rhode Island, USA. ' $\mathrm{He}$ is an Associate Professor in the department of Sociology, Afe Babalola University, Ado-Ekiti, Nigeria.

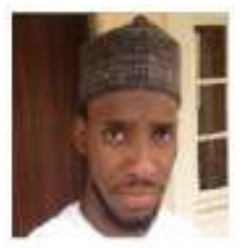

Ahmad Ahmad Nuhu is a graduate of Mass Communication from Ahmadu Bello University Zaria. He is currently a Graduate Student in the department of Conflict, Peace and Strategic Studies at Afe Babalola University Ado-Ekiti, Ekiti State.

Citation: Adeyemi J. Ademowo, Ahmad Ahmad Nuhu. "Indigenous Knowledge and Conflict Management in Africa : A Study of Proverb Use in Conflict Management among Hausas of Northern Nigeria." International Journal of History and Cultural Studies (IJHCS), vol 3, no. 4, 2017, pp. 36-44. doi:DOI: http://dx.doi.org/ 10.20431/2454-7654.0304004.

Copyright: $\odot 2017$ Authors. This is an open-access article distributed under the terms of the Creative Commons Attribution License, which permits unrestricted use, distribution, and reproduction in any medium, provided the original author and source are credited. 